\title{
Minor anomalous left atrial branch originating from right coronary artery
}

\author{
K R Sunil Kumar, Himanshu Mahla, M C Yeriswamy, \\ Cholenahally Nanjappa Manjunath
}

Department of Cardiology, Sri Jayadeva Institute of Cardiovasular Sciences and Research, Bangalore, Karnataka, India

\section{Correspondence to}

Dr K R Sunil Kumar, drsunilkumarkr@gmail.com

Accepted 10 February 2014
CrossMark

To cite: Sunil Kumar KR, Mahla $\mathrm{H}$, Yeriswamy MC et al. BMJ Case Rep Published online: [please include Day Month Year] doi:10.1136/bcr-2013201074

\section{DESCRIPTION}

A 43-year-old man presented with effort angina Canadian cardiovascular society class III. The patient has been a chronic smoker and diabetic for 15 years. Cardiac examination and 12-lead ECG was normal. Echocardiogram revealed normal left ventricular ejection fraction with no regional wall motion abnormality. He was electively taken for coronary angiogram which revealed small calibre left circumflex (LCX) which was diminutive, diffusely diseased and subtotally occluded distally (figure 1; video 1). Left anterior descending artery (LAD; type II) had subtotal occlusion in mid segment (figure 2; video 2). Right coronary artery (RCA) was dominant with insignificant stenosis in proximal-to-mid RCA (figure 3; video 3). Posterior descending artery had ostioproximal severe disease $(1.5 \mathrm{~mm}$ vessel) with moderate disease in distal segment (video 3). Posterior left ventricle (PLV) had mild disease (video 3). One branch from PLV was coursing above the origin of RCA (figure 3; video 3 ). This was a very lengthy branch with termination above the origin of RCA and appearing as wire around the heart. Initially we were confused about the name of this branch. After carefully reanalysing the angiogram, we concluded that it is the large left atrial branch originating from PLV (of $\mathrm{RCA}$ ) in the presence of diminutive LCX.

The patient underwent angioplasty with stenting to $\mathrm{LAD}$ and is doing well on follow-up.

Sometimes we see things in the catheterisation laboratory which we have not seen previously in our life, like this large left atrial branch from PLV.

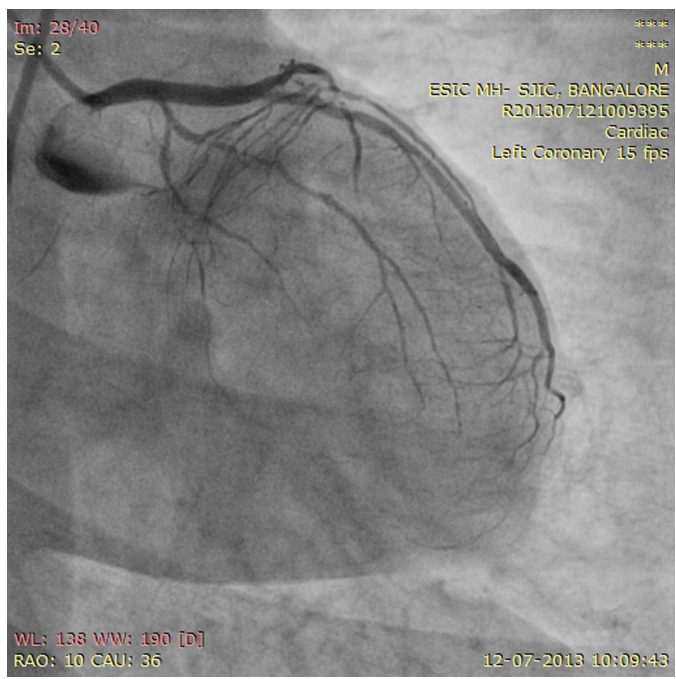

Figure 1 Right anterior oblique caudal view (left system) showing diminutive left circumflex with diffuse disease followed by subtotal distal occlusion.

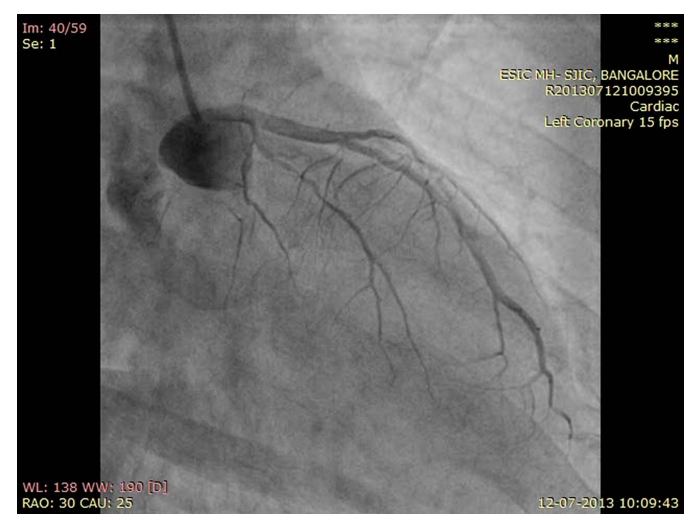

Video 1 Right anterior oblique caudal view (left system) showing diminutive LCX with diffuse disease followed by subtotal distal occlusion.

To the best of our knowledge we are reporting for the first time, the origin of a large lengthy left atrial branch from PLV (of RCA). Significance of detailed knowledge of left atrial branches during catheter ablation for atrial fibrillation ${ }^{1}$ has been stressed by earlier studies.

Atrial branches of coronary arteries between the left atrial appendage and left superior pulmonary vein and the branches between left inferior pulmonary vein and mitral annulus can be problematic while atrial fibrillation ablation. Recurrence of atrial fibrillation can occur due to protected myocardium near atrial branches.

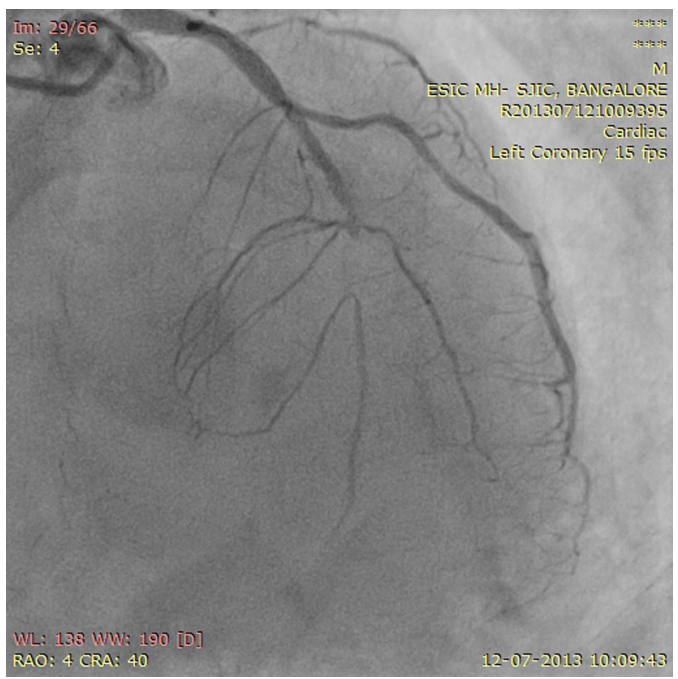

Figure 2 Right anterior oblique cranial view (left system) showing mid left anterior descending artery with subtotal occlusion. 


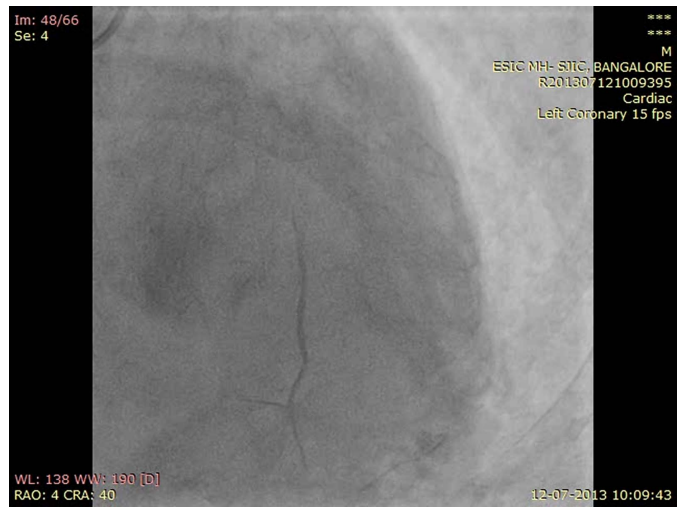

Video 2 Right anterior oblique cranial view (left system) showing mid LAD with subtotal occlusion.

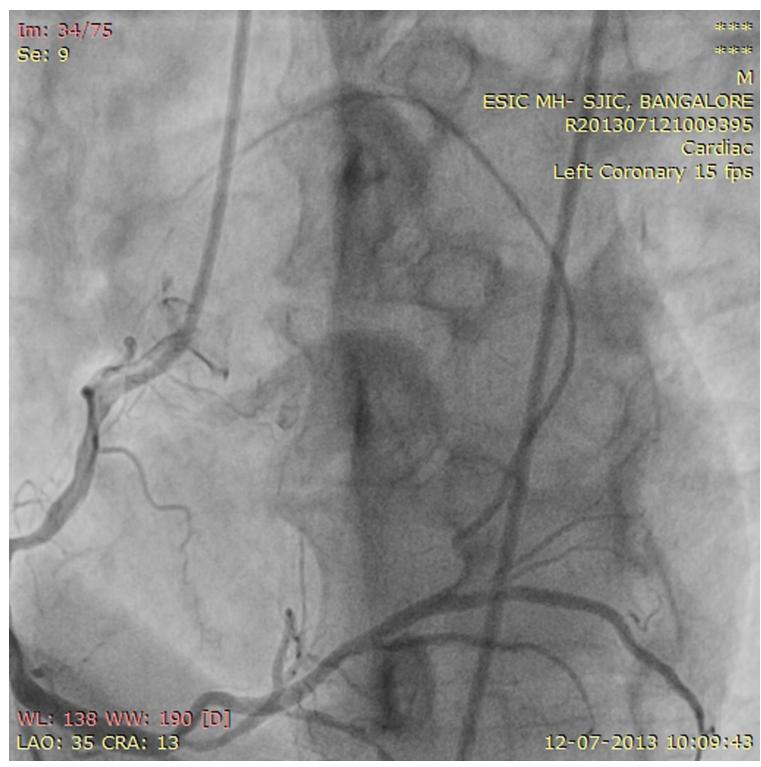

Figure 3 Left anterior oblique cranial view (right system) showing large left atrial branch originating from posterior left ventricle.

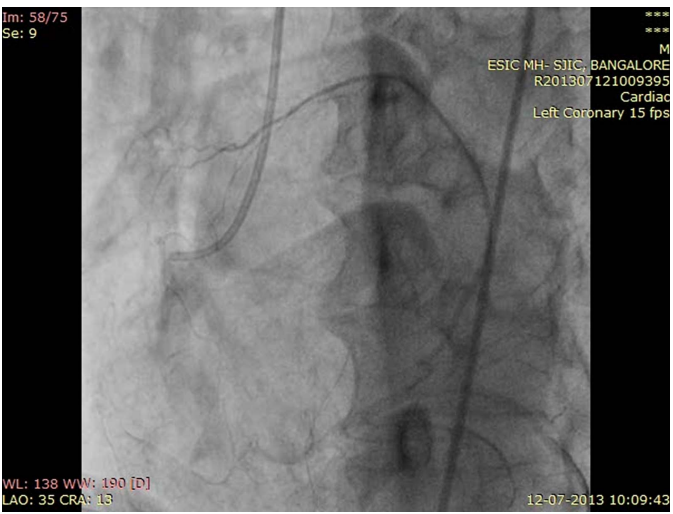

Video 3 Left anterior oblique cranial view (right system) showing large left atrial branch from PLV with insignificant disease in RCA and significant severe disease in ostioproximal PDA.

\section{Learning points}

- Left atrial branch can arise from right coronary artery in the presence of diminutive left circumflex.

- Even minor coronary anomalies should be kept in mind before entering to catheterisation laboratory.

- Left atrial branch anatomy should be correctly delineated before catheter ablation for atrial fibrillation.

Contributors All authors were involved in patient care. Article preparation was done by HM and KRSK. Angiogram was carried out by MCY and the finishing touch was given by CNM.

Competing interests None.

Patient consent Obtained.

Provenance and peer review Not commissioned; externally peer reviewed.

\section{REFERENCE}

1 Yano $A$, Igawa 0 , Adachi $M$, et al. Left atrial branches of coronary arteries; clinical implications related to linear catheter ablation for atrial fibrillation. J Interv Card Electrophysiol 2009;25:141-4.

Copyright 2014 BMJ Publishing Group. All rights reserved. For permission to reuse any of this content visit http://group.bmj.com/group/rights-licensing/permissions.

BMJ Case Report Fellows may re-use this article for personal use and teaching without any further permission.

Become a Fellow of BMJ Case Reports today and you can:

- Submit as many cases as you like

- Enjoy fast sympathetic peer review and rapid publication of accepted articles

- Access all the published articles

- Re-use any of the published material for personal use and teaching without further permission

For information on Institutional Fellowships contact consortiasales@bmjgroup.com

Visit casereports.bmj.com for more articles like this and to become a Fellow 